\title{
RESEARCH
}

\section{Parliamentary 'Theatre', Dignity and the Public Side of Parliaments}

\author{
Henk Te Velde \\ Leiden University, NL \\ H.te.Velde@hum.leidenuniv.nl
}

The comparison between parliaments and theatre has often been used to criticize the superficial show that hides the real societal issues politics should be concerned about. In this contribution, the comparison between theatre and parliaments is a heuristic tool to show that parliaments really offer a certain form of theatre. The contribution concentrates on the use of theatrical metaphors in and around nineteenth-century British and French parliaments, that were then seen as the most important parliaments and certainly as the most important parliamentary 'stages'. The 'theatrical' side of parliaments shows the ambiguity as well as the crucial importance of their public nature. Parliaments were seen as providing serious, uplifting theatre but also vulgar theatricality. The serious Burkean theatre and its counterparts in the French Restoration and July monarchy or the sober Netherlands parliament provided the framework for good discussions: a strict separation of participants and audience, respect for rules and traditions of debate, exchange of arguments more or less according to the classic unities of tragedy. However, the Burkean conception of moral theatre risked having the elitist effect of excluding a public not versed in its rules, or whose main concerns were not addressed in the ongoing debates. That is why elements of demotic or popular theatricality have helped to democratize parliaments, make them more accessible to the public at large and mobilize the constituency by offering them clear choices between issues and protagonists. The function of the debates could be better understood by analysing them as theatre plays with crucial roles for the main actors and the public.

Keywords: Theatre; Parliaments as Theatre; publicity of politics; 19th century; British Parliament; French parliaments; Dutch parliament

Calling a parliament a theatre or its deliberations 'theatrical' has often been used as a form of criticism or satire. The comparison between politics and theatre is a stock-in-trade of political journalism, used to criticize the superficial play or show that hides the real societal issues politics should be concerned about. The comparison has also been used as a compliment, though, and it has quite recently been taken as a more or less neutral term of analysis. The linguist Cornelia Ilie, for instance, has argued that parliament and theatre have a lot in common. Both words can indicate a building, an activity type and a certain world or category of agents. They both also have an audience. There are also important differences. Parliament is about 
winning and losing and decision-making, whereas theatre is about public entertainment and cultural education, she says (Ilie 2003). It could even be argued, however, that parliament is also about entertainment and education. There is a long tradition of studies that have not only drawn attention to similarities between politics and theatre, but have also put forward that politics and parliaments are in essence theatrical, in particular with respect to audiences (Rai and Reinelt 2015). Currently, these studies often use the terms 'performance' or 'spectacle' to describe theatrical aspects of politics (Rai and Reinelt 2015, Yeandle et al. 2016 Green 2010, Finlayson 2017). For at least two reasons I prefer theatre: in this way, the analysis can stay closer to the actual use of words in the nineteenth-century sources that form the empirircal basis of this contribution, and, moreover, the ambiguities of the term theatre help to tease out the different layers of meaning attached to the spectacular or performative side of parliamentary action.

The comparison between theatre and politics is a heuristic tool to understand important aspects of what politics is about. At a theoretical level, it could be argued that politics really is to a certain extent a form of theatre, or it could, at least, be argued that it clarifies some aspects of politics to look at it that way. The comparison is much more than just another scholarly metaphor. This becomes apparent when we study the various meanings that have been attached to the public or 'theatrical' side of parliaments over the last two centuries. Parliamentarians and parliamentary commentators themselves have been using theatrical language for a very long time. In order to find out what we can learn from seeing parliaments as theatres I will mainly use sources from the nineteenth century, the time when parliaments were the centre of politics and when the opposition between 'theatre' and 'reality' did not seem nearly as absolute as it does today (Voskuil 2004). This contribution will concentrate on the use of theatrical metaphors in and around British and French parliaments, which were viewed at the time as the most important parliaments and certainly as the most importan parliamentary 'stages'. ' Second, this contribution will show that the publicity of parliaments in a certain sense turns them into theatres that have audiences. Only by concentrating on the 'theatrical' side of parliaments can we fully appreciate the ambiguity, but also the crucial importance, of the public nature of parliaments. Even those who are interested in this theatrical quality will concede that a politician who is merely an actor forgets the principles, causes and concrete measures that politics are about. They could counter, though, that a politician who forgets to be an actor at all, neglects the public side of politics and is not capable of maintaining a good relationship with the voters or the audience.

Politics is more than just superficial play-acting. A historian wrote that a study of nineteenth-century politicians, such as the British conservative leader Benjamin Disraeli and the British liberal leader William Gladstone, is 'dealing with men whose function was histrionic, whose words and actions were meant to be ambiguous and who are most likely to be understood, not by asking whether they believed what they wrote but by showing what role each cast himself for in the political world' (Cowling 2005 [1967]), but who does not say much more about the theatre of politics. The phrase implies that a political leader had to be sure of his lines and had to know what his public persona was. The stories politicians told, the way they told them and the consistency of their stories were all equally important. Taking theatricality seriously will also help to see what we can learn from a cultural study of parliament. Parliamentary studies usually borrow more frequently from political science than from cultural history, and we should, of course, not forget that parliament is a political battlefield but still it has a side that best could be explored by taking a cultural perspective. This is not confined to outward appearances, to 'theatrical' superficialities, but could also include 'dramatic' functions of politics: agenda setting, staging' political differences, conferring meaning, binding people together, and 'moving' them. Moreover, it has been argued that parliament also offers drama in the sense of the classical unities of action, time and place of dramatic tragedy (Roussellier 1997, 10). These unities are more than simple rules of a game because a game does not have a plot or a unique story as parliamentary debates do. I will concentrate on theatre as an element of the public side of parliaments, but will eventually connect the discussion about parliamentary theatre with the nature of the debates at its core.

\section{Publicity of Parliaments}

Representative government fulfills many roles, but for this contribution two are most important. On the one hand, there is the relatively autonomous deliberative side of debating and passing laws in parliament. On the other, representative government should give the people a voice, should represent them. These roles are not mutually exclusive, and it could be argued that one of the best ways to represent the people is making good laws for everyone. However, a tension remains between the two roles. Although nobody would deny that representative government should represent the people, the public has often, albeit implicitly, been seen as disturbing the real business of parliament, meaning its constitutional functions such as passing laws, forming and supporting governments, and monitoring them. As a rule 'playing to the gallery' is not used as a compliment, but as a criticism of politicians who do not really engage in exchanging arguments, but try to flatter the audience or public instead.

Parliamentarians should act as impassionate judges many commentators have felt. When an American chief justice visited Irish and English courts in 1910, he 'was much impressed by the business like appearance of the proceedings. It seemed as if counsel, jury and Judge were co-operating in the work of finding out the truth. There was no effort at dramatic effect, no "playing to the galleries," Indeed there was rarely any audience and never a large one, the court room being too small for a crowd.' To his satisfaction, the judges were treated with 'courtesy' and 'deference' (Emery 1910, 229). There is, however, at least one difference between a parliament and a courtroom. Parliament would lose most of its significance without a public, whereas, at least theoretically, courts could confine themselves to being public in the sense of transparency. Ever since parliaments opened up to the public at the end of the eighteenth century, many parliamentarians and many students of parliament have rejected participative publics and also tried to limit publicity to transpararency. Even a radical critic of established politics such as the philosopher Jeremy Bentham - who wrote the first theoretical reflection about parliamentary rules at the end of the eighteenth century - conceived of the role of the parliamentary public in this light. He preferred the 'cool' distant publicity of newspaper reports to the direct publicity of noisy galleries because these noisy galleries would stimulate the victory of 'the excitements of oratory' over 'logical proofs' (Bentham 1999: 36, 62, Mulvihill 2004, 59-60). Bentham advocated indirect publicity through newspapers because this type of publicity prevented that parliamentary actors would 'cultivate the eloquence of seduction, rather than the eloquence of reason' and also that 'they will become tribunes of the people, rather than legislators' (Bentham 1999, 36). According to him, the size of a parliament should be much smaller than 'an ordinary theatre' because a member of parliament could not be supposed to have 'the strength of voice and the declamation of an actor' (Bentham 1999, 62).

${ }^{2}$ Cf. the ironic title of parliamentary sketch writer Hoggart, 2002. According to Harrison, 1993/1998: 112, the expression originated in the $19^{\text {th }}$ century and 'is now used generally in many walks of life for those who consciously seek popular attention and adulation '. 
Bentham advocated the monitoring function of the public whose supervision could prevent or check many abuses, but this public opportunity remains rather abstract. He does not really seem to like actual participation by the people, and he does not pay much attention to the people explicitly. That is understandable because most conceptions of representative government have wanted to protect the freedom of the representatives, which could be threatened by direct interference of the public that attend parliamentary sessions. On the other hand however, parliament could never ignore the concrete public completely. This ambiguous position was reflected in the discussion about the relationship between the parliamentary 'actors' and their audience. Bentham wrote his treatise in the context of the French Revolution when French representatives were interested in British parliamentary rules for their own new National Assembly (Blamires, 2008). The radical French revolutionaries whom Bentham would qualify as reprehensible tribunes of the people were quite ambiguous about the meaning of theatre themselves. They applauded that theatre plays moved an audience, and that plays produced unanimous emotions of an active audience, but they were afraid that superficial political actors bedazzled the public. They liked publicity in all its forms, but not necessarily theatricality (Maslan 2005). Hardly anyone has ever really simply embraced the theatricality of politics.

In recent years social scientists have criticized 'drama democracy' as an artificial form of politics driven by the media and a perversion of proper representative politics with its almost 'ascetic reason'. 'A frightened, upset, mistrustful society demands theatre'. They were assuming that this is a quite recent development (Elchardus 2002: 68, 73). That is why they seem to suggest that it is possible to remove the 'theatrical' side of democracy in general and parliaments in particular, and just concentrate on the real business instead. However, the theatrical side is no recent invention. It belongs to the nature of parliament and analysing this dimension could yield important insights into the nature of parliamentary politics. It is important to note that calling parliaments 'theatrical' is not just another comparison. In contrast to many comparisons that are simply metaphoric, it could be argued that parliament to a cer tain extent is theatre. It has perhaps always been the case, and as parliamentary historians well know, the use by commentators and parliamentarians alike of the comparison between parliament and theatre is already very old. It did not first emerge with the age of mass media unless one would count eighteenth-century newspapers with their limited circulation as mass media. This is not to say that everything that is being denounced as 'theatrical' is a necessary, let alone useful, element of parliament, far from it. Rather this is a plea to take the ambiguous nature of parliament seriously: it is a deliberative and a theatrical system, and theatre could be useful or problematic.

Taking the ambiguous nature of parliamentary 'theatre' seriously would also help to address a problem that contemporary theorists of 'deliberative democracy' have struggled with. They tend to define ideal debate as a dispassionate exchange of rational arguments and do not know what to do with the public, besides educating it to accept this type of politics (e.g. Finlayson (2015) who criticizes this attitude). Yet it makes a real difference to debates, (1) whether they are conducted in front of an audience, and also (2) whether that is a live audience or a distant audience of readers. If we want to understand the nature of parliamentary debating we have to take the audience into account. Once we realize that 'playing to the gallery' to a certain extent belongs to parliaments, we can start to differentiate between the different aspects of the theatricality of parliament.

\section{Dignity and Publicity}

From at least the end of the eighteenth century, negative and positive uses of the comparison between parliament and the theatre have been distinguished as the example of MP and philosopher Edmund Burke shows. He distinguishes between good drama and bad theatricality. This was hardly original because most actors and playwrights themselves distinguished between debased, shallow and manipulative theatrical effects and dramatic effects that moved people and stimulated them to behave as sensitive moral beings (Maslan 2005, 4). In practice, Burke links this distinction with two competing qualities of parliament: dignity and publicity. For Burke dignity was the most important element. According to him, real theatre plays were a means for the 'Instruction' and 'Entertainment' of, in particular, the elite and members of parliament. There was a lot to be learned from going to the theatre, because parliamentarians had to perform on a 'publick Stage' themselves (Hindson and Gray 1988: 6, 21). This was an elevated stage, both in the sense that everybody could observe it, and in the sense of being eminent and distinguished. The 'actors' on this stage needed a special public. 'Spectators' whose 'whole Delight is in their Eyes' would not do because they would be just passive and mindless onlookers who came to be entertained by the spectacular fights (Hindson and Gray 1988, 132). Instead, parliament needed a serious and thoughtful 'Audience' who participated in politics because they really came to listen to the debates.

In the eyes of Burke, Parliament was clearly 'dignified' in the sense that Walter Bagehot would later give to that word in his English Constitution of the 1860s (Bagehot 2009). In Bagehot's famous distinction between the sober and effective 'efficient' and the magical or theatrical 'dignified' parts of the constitution, Parliament mainly belonged to the efficient parts. However, this was still a mystification even for his own time, let alone for the time when Burke was writing. Burke would have rightfully argued that Parliament's efficiency was enhanced or perhaps even produced by its dignity. It had authority because it was an elevated stage. The public paid attention to what was being said in parliament and there was a respectful distance between the 'audience' in the galleries and in the country, on the one hand, and, on the other, the political 'actors' on the 'stage' who could act efficiently and responsibly exactly because of this distance. They did not present a fairy tale to the common people, which was how Bagehot presented the dignified aspect of politics, but a dignified play which allowed for public discussion and finding solutions for political problems, and was thus 'enacting' politics.

That Burke saw parliament as a theatre did not mean that he liked all forms of parliamentary theatre which he made abundantly clear in his classic comments on the French Revolution. He preferred a kind of dignified Shakespearean drama to noisy theatricality. According to him, the National Assembly in the French Revolution was 'theatrical' in the bad sense of the word: shallow display, no substance, but a lot of noise. The National Assembly produced a farce of deliberation without dignity. 'They act like the comedians of a fair before a riotous audience', composed of a 'mixed mob of ferocious men, and of women, lost to shame'. 'As they have inverted all things, the gallery is in the place of the house' (1790). Burke started a tradition of conservative criticism of the Assembly. Almost a hundred years later the famous conservative French historian Hippolyte Taine used similar invectives in his endless diatribe against the National Assembly: superficial 'theatrical exhibitions', opera, melodrama, cheap comedy before an interfering public. Taine used all possible theatre metaphors (Taine 1899: I, 54-57, 146, 149, 172, 179-181, 227).

These comments are more vehement than the criticism of drama democracy today, but the central idea seems to be more or less the same. Politics should be a serious discussion of serious matters, not a shallow and dishonest comedy to dazzle the public. Today, critics blame the modern media for causing this dramatic change in politics, but Burke already attacked it at the end of the eighteenth century and blamed it on bad ideas and an hysteric audience. The interesting thing is that you will find this type of criticism at least ever since the radical publicity of parliaments was invented at the end of the eighteenth century. The idea that parliament is a stage and a theatre became much more convincing once parliaments had become open to a larger audience. 
Burke commented on the behaviour of both politicians and their audience. Members of parliament should realize that they were acting on an elevated stage, and this demanded grandeur and elegance. It did emphatically not imply pandering to the gallery, and least of al to 'a riotous audience'. French revolutionary parliamentarians had lost their dignity because they listened to the rowdy people that were attending the Assembly and had turned the world upside down because now 'the gallery is in the place of the house'. This way of putting it shows how Burke viewed the audience. They should be subservient to the parliamentarit shows how Burke viewed the audience. They should be subservient to the parliamentar-
ians: they were not supposed to act along with the political actors, but should be silent and know their place. Burke was advocating an active audience (instead of spectators in the sense of just passive thrill seekers), but active in a peculiar meaning: according to the rules of the elevated stage of parliament. He went against the eighteenth-century tradition of an audience of dramatical works, who clearly showed their approval or disapproval and who were more powerful than the press in deciding the fate of theatre plays and melodramas (Swindells 2001: 159, footnote 75).

Comments on the 'theatre' of parliament often had a clear political message. Burke's radical opponent, Thomas Paine, realized this perfectly well when he accused Burke of presenting the story of the Revolution in the form of a 'dramatic performance'. According to this radical critic, it was not French revolutionaries but Burke himself who turned politics into theatre (Paine, The Rights of Man, quoted by Hindson and Gray 1988: 39-41). The distinction between good drama and bad theatricality is, at least partly, in the eye of the beholder Burke had a clear conservative conception of how an audience should behave: the audience should be deferential, their thirst for 'theatricals' or 'spectacles' should be ignored and they should, instead, be educated and disciplined. There is a strong parallel, even in the words that were used, between this political evaluation and the evaluation of the theatre of the time. Burke described Parliament as a Shakespearean drama and the National Assembly as a farce or burlesque put up by 'comedians of a fair'. This was a distinction between high and low culture and between classic theatre and the newly emerging melodrama of the age (Poole and Sanders in Yeandle 2016: 24, 54)

The development of mass politics in the nineteenth century has often been likened to melodrama (Hadley 1995, Yeandle et al. 2016). Melodrama was a popular form of theatre about moral issues which emerged in the late eighteenth and early nineteenth centuries, with a dichotomy of good and evil, and heroes and villains to embody these qualities. Many nineteenth-century critics of 'shallow' parliamentary theatre would use words that seemed to be derived from the language of 'cheap' melodrama. However, the distinction between the two types of theatre was not stable. During the nineteenth century classic theatres began programming melodrama or sensational plays because that was the way to remain economically viable. On the other hand, there were also popular adaptations and performances of Shakespeare, and the absolute distinction between the two 'levels' of theatre began to disappear. Gladstone favoured the uplifting function of theatre as moral education, but his taste was mixed, he also liked to attend popular forms of theatre (Heinrich 2016).

Meanwhile the positive side of the relationship between sensational theatre and the audience was also commented on. Theatre critics appreciated the moral involvement of the audience produced by the face-to-face interaction of sensational theatre. The mostly lower-class audience of melodrama felt free to express loudly their admiration or disapproval of what they saw and heard. In the 1830s, parliamentary journalist James Grant noted the similarities between audience responses to sensational theatre and to radical politics (Voskuil 2004: 64-65, 71, 90-91). ${ }^{3}$ In this case the audience did not only attend, but was also actively

3 Parliament is curiously absent from this book; Voskuil is e.g. quoting remarks about theatre but not about parlia ment from parliamentary journalist Grant, 1836 . involved. This was something Burke had seemed to advocate by his distinction between spectators and audience, but he had reserved his praise for elite drama, whereas others underlined that popular theatre was in fact more effective in this way. Burke's idea of an active audience was different: it meant intellectual involvement instead of the clamorous expression of moral judgment by melodrama and its audience. Melodrama and sensational theatre were the opposite of what Burke had in mind, as the audience almost acted along with the cast on the stage, as it had done during the French Revolution that Burke abhorred.

Some of the theatrical elements of the House of Commons already existed before the opening of parliament to the public at the end of the eighteenth century. Orators already acted before an audience: the audience of their fellow MPs. The poet Byron sat in the House of Lords for a short period in the early nineteenth century. He writes: 'The impression of Parliament upon me was that it's members are not formidable as Speakers but very much so as an audience' (Marchand 1979, 16). The new publicity gave more popular legitimacy to the rhetoric and the theatrical quality of parliament. In the middle of the nineteenth century the respectable Times wrote that 'Parliament is our theatre'. The Romans had gladiators, Spain had bullfights, but British 'educated society' loved this type of stage fight (The Times 4 February 1859, cf. Bevis 2007, 24, Hawkins 2015, 113).

It could be argued that the audience in the galleries at first consisted mostly of experts in parliamentary politics. The taste of the audience in the galleries resembled the taste of the members of parliament themselves. They all participated in the 'London season', when all cultural and political events were staged in the capital (e.g. Davidoff 1973, changes after 1880: Cannadine 1999, 341-355). They belonged to the same social strata of 'educated society', went to the same parties and clubs, shared the same cultural education. The connoisseurs of parliamentary theatre and rhetoric went to the House of Commons in particular on days when the great orators debated. They appreciated rhetoric in the classical vein, and references to classical theatre scenes came naturally to them. Historian and MP Thomas Macaulay - participant and audience at the same time - wrote on the occasion of the passing of the First Reform Bill in 1832: 'Such a scene as the division of last Tuesday I never expect to see again. (...) It was like seeing Caesar stabbed in the Senate House' (Swindells 2001, 16). The audience and the parliamentarians themselves cheered as partisans who were keen that their side should win, but they also came for the dramatic fight between great orators. Politics was about power and interest, but also about culture and emotions, and the audience wanted to be educated, entertained and moved, too. Parliament also fulfilled the functions that Cornelia Ilie ascribes to theatre: public entertainment and cultural education. This was important because it helped to legitimate parliament. People actively supported this type of politics because they held certain views and ideals, but also because parliamentary politics was a part of their life and something they found culturally attractive. It was serous business, a passion and a pastime at the same time.

For a long time, this was first and foremost true for the aristocratic and respectable elite that often had the vote and certainly belonged to the circles that mattered politically. It is true, in a number of constituencies that the common people were very active in the melodramatic battle of the 'hustings' at election time and they were aware of national political issues (O'Gorman 1992), but they did not have the means to follow in detail what was going on inside the House of Commons itself, until the mass press (also regional press) provided them with the information in the second half of the nineteenth century. Within the elite, Burke's conception of the parliamentary elevated stage prevailed until the mid-nineteenth century. It meant that parliamentary politics was a respectable art, with actors who were conscious that they had to play a part in a dignified drama, visible to all, but at a distance from the common people. From the second Reform Bill onwards the common people increasingly entered parliamentary politics. The 1870 s and 1880 s were a crucial period in this respect. On the one 
hand, classic elite culture was trickling down. A new audience was introduced to parliamentary politics by the early newspapers for the masses. They used a new genre, parliamentary sketches, to give their readers an impression of the world of the House of Commons, and the way parliamentary debates were conducted. Although the first sketches dated already from the first half of the nineteenth century (e.g. references to Grant and Dickens in Gaunt 2016, 223-224), in the 1870s and 1880s popular journalists such as Henry Lucy turned the genre into a common feature of national and even regional newspapers. One of the sketch writers, T.P. O'Connor, Irish MP and famous journalist, likened leading politicians Disrael and Gladstone in his sketches and in his speeches in the House to the star actress of the classical theatre, Sarah Bernhardt, and to Shakespearean characters. ${ }^{4}$ In general, sketch writers described parliamentary politics as a classic and encoded world; their ambition was to introduce their uninitiated audience into the culture of this fascinating world.

At the same time another 'theatrical' development was going on, which did not entail a trickling down of elite culture but almost the opposite. Melodrama was popular as a form of theatre, but parliamentary politics could also be presented in this way, especially in the 1870s and 1880s when two heroes or villains were available: Disraeli, the protagonist of the Conservatives, and Gladstone, protagonist of the Liberals. They were opposite political characters, with contrasting political views, conceptions of politics and personalities. Disraeli was a House of Commons man, an actor who did not hide that he was acting, and he used a lot of irony. Gladstone was a very serious moral crusader, who acted as the honest champion of the respectable common people. They were the ideal protagonists for journalists and sketch writers, and their duel attracted a lot of attention outside the traditional audience of Parliament. Gladstone had a classic upbringing in Eton and Oxford, but he also had a lot of moral fervour. He acted his part admirably in the classic parliamentary form of theatre as well as in the new melodramatic mass politics outside parliament, which explains his great popularity and his dominance over liberal politics. In the terms used by Bentham more than half a century before, he certainly was a tribune of the people and he seduced his audience, but he was also a reasoning legislator. He was very good at keeping the balance between the dignity of parliament and its dramatic or theatrical qualities (Matthew 1995. Wickham 1998, Smith 1996 Aldous 2007).

\section{Melodrama and Democracy}

It could be argued that every modern parliament has to find a balance between dignity and theatricality. However, this balance will be different in each case. Even though in France many commentators underlined the importance of dignity too, the element of theatricality with large gestures was more prominent in French than in British parliaments. Burke immediately likened the new noisy parliament that emerged during the French Revolution to a cheap farce. The noise was the result of the choice for absolute publicity. This publicity had an enormous effect on the French revolutionary parliaments after 1789. The new National Assembly contained huge public galleries which could accommodate as many as two thousand spectators. The assembly itself was already huge because it consisted of more than a thousand members. It was surrounded by an even bigger crowd of spectators, cheering and booing

${ }^{4}$ O'Connor 1885: 55 (Gladstone and Bernhardt), Gladstone's House of Commons 279 (Disraeli and Shakespearean characters); also House of Commons 13 June 1882, 1062-1063. I also deal with sketch writers and the 'theatre' of the British parliament in Te Velde 2003

3 There is an enormous literature about these political figures. Gladstone's best biographer pays attention to his histrionic side in Matthew, 1995; see also Wickham, 1998; for Disraeli as actor among other things, Smith, 1996; a useful impression of their 'duel' e.g. in Aldous, 2007. and making all other possible noises. It was worth attending because the constitution and the fundamental rights and issues of the country were at stake in its debates, but it was also interesting and amusing in its own right. It is no wonder that the Assembly attracted a lot of visitors, ranging from the Paris beau monde to the common people and to foreign visitors. English visitors were struck by the habit of many French parliamentarians to present or read prepared texts. One of the differences Cornelia Ilie sees between actors and members of parliament is that actors follow scripts and reproduce texts whereas the latter only follow rules and produce texts that will be recorded in parliamentary proceedings afterwards. At this point, however, many French MPs were actors in the sense that they performed with texts prepared by others. English visitors thought it was strange that French MPs lent themselves to a role as 'acteur de théâtre' (Young quoted by Dodu 1911, 69). In fact, the greatest orator of the day, Count Mirabeau, was praised exactly because he was such a marvelous actor, with the diction, the charisma and the theatrical appearance of a great actor (who had missed his calling), even though he held rather moderate constitutionalist views (Dumont 1832, 149-151, Goodden 1984, 206, Heurtin, 1999).

In 1792 the German composer and music critic Johann Friedrich Reichardt belonged to the category of foreign visitors (Reichardt 1892: 202-218, 235, 241, 244, 326-327). The night he arrived in Paris, he went to the theatre. The following day he went to the Assembly and at night again to the theatre. Because the tickets for the Assembly were in demand, there was a trade going on, and Reichardt complained that the tickets were expensive. But he went to the Assembly partly for the same reason as he went to the theatre, to learn and to be amused. Often the noise was so loud that he could not understand a word of what was being said, but at some point he was even moved to tears by a wonderful speech, and a sophisticated discussion on a technical matter between experts convinced him that these debates were really useful, too. However, he abhorred the noise and the interference by the public, especially the common people who were sitting in the public galleries that were accessible to everybody, a place where a respectable man like himself did not go.

Reichardt visited Paris during the radical phase of the Revolution. When the parliament had opened in 1789 it was still a bit different. The daughter of Minister Necker would later become famous as the author Germaine de Staël or Madame de Staël. In 1789 she visited the public galleries almost every night, together with a lot of other respectable and aristocratic ladies. They were elegantly dressed and went to the parliament almost as they would have gone to the theatre. But they were also fascinated by the public debates, the oratorical duels that were going on and the political issues that were at stake. According to Madame de Staël, Paris high society flourished as never before. The restrictions of the Old Regime had gone but politics were still dominated by aristocratic codes: this was how a parliament should function (de Staël 2000: 32, 228-229, Fairweather 2006: 97-98).

Madame de Staël liked quality drama, but not cheap melodrama. During the nineteenth century the use of theatre metaphors would waver between these two conceptions. However because the revolutionary French parliament was so enormous and immediately so intensely public, it was difficult to see it as high Shakespearean drama. This high conception of politics was heard mostly in the later period of elite politics in the first half of the nineteenth century, between 1814 and 1848. During that period a respectable and aristocratic conception of parliamentary politics would dominate bourgeois France. After the fall of Napoleon a parliament was founded, based on restricted suffrage. The now much smaller public galleries could contain no more than a couple hundred spectators and they as well as the readers of the newspapers mostly belonged to the same class as the members of the new parliament themselves. Aristocratic ladies again flocked to the public galleries and judged the performance of the parliamentary actors. Even progressive liberals thought that a cultivated public 
should have the last word. As despotism killed creativity and popular sovereignty produced melodrama and farce for the common people, a proper parliament needed a public with taste (Goblot 1995: 420-422, 433). Not everybody was convinced, though, that the public in the galleries matched these criteria. The galleries were most crowded when great orators would perform or when an incident or row was expected. Critics said that the Chamber of Deputies had turned into a variety theatre for spectators in search of a scandal ${ }^{6}$

Delphine de Girardin was a brilliant society lady, the wife of a politician and press lord. In the 1830s she started a very successful newspaper column in her husband's journal about Paris society life. She included many remarks about parliamentary life as well. She thought that boring laws were more important than exciting debates, and criticized the habit of the Parisian Monde to go to the parliament in order 'to be amused'. She writes: 'We believe that everything that gives an air of theatre to the national representation deprives it of its dignity. Those who assist the sessions of the Chamber are [she meant: should be] simple witnesses'.? However, the parliament was a central element of Parisian cultural life and the most important topic of discussion in the conversation of the famous salons that thrived at the time Delphine de Girardin was criticizing a very respectable form of theatre. The revolution of 1848 destroyed the reputation of the elite parliament of the July monarchy, but the cultural appreciation was important for the legitimacy of parliamentary politics in general. Until at least 1848 , this legitimacy was based to a large extent on the elite culture that judged parliament as it would judge the theatre. It was an aspect of the parliamentary audience Delphine de Girardin did not take into account.

Meanwhile the theatrical quality of the French parliament was underlined by the actual building. After 1789 it had taken some time before the parliament had found a proper meeting place. This was a matter of practical concerns, but parliamentarians also had to figure out the best physical form for a parliament. They were already concerned with the 'physical sites of democratic performance' (Parkinson 2012) and found out that the hemicycle was practical, and, contrary to a full circle, also symbolically open to the public (Heurtin 1999). During the July monarchy, the parliament in the Palais Bourbon was decorated and furnished in the way we can still see today. With its decorations and red carpets, it really has the atmosphere of a theatre, an impression reinforced by the rostrum from which orators delivered their speeches. Sober liberals who preferred quiet debates to oratorical display - or at least said that they did - thought that the French parliamentary building invited theatrical display and used the British parliament as a counter-example because MPs had to speak from their seats, and the building seemed to be designed for conversation, albeit adversarial conversation (De Staël-Holstein 1829, 267). These kinds of remarks underestimated the theatrical side of the British hall, which was underlined by the rituals surrounding the Mace, the dispatch box and, in general, debating rules.

There was, however, a much more radical way of seeing the French parliament as a theatre. Only a couple of years before Girardin, a radical writer commented on the liberal political changes of 1830 . He advocated the founding of political clubs everywhere in the country, in order to turn parliamentary politics into something common people could identify with. On top of this, he also thought that there was a 'perfect analogy' between 'representative gov ernment' and 'actors' in a 'theatre'. The nation was the audience of the representatives and because they paid for the whole thing, they had the right to supervise and criticize. If the parliamentarians did not perform well, the audience would hiss at them (Dinocourt 1830: I, 2). The comment is reminiscent of thoughts that were expressed during the French Revolution when another radical writer thought that 'the parterre' or common public should have the liberty to 'siffler' (hiss at) theatre actors, but also at 'the entire Parlement'. If you came to think of it, 'the first article of our liberty should be the liberty of the sifflet' (Friedland 2002, 268).

The type of audience these critics had in mind was clearly not the respectable elite audience of classic drama but rather the vocal audience of melodramas. According to one modern specialist, audience response, be it laughter, hisses, or tears, is perhaps the single constant criterion in the definition of [nineteenth-century] stage melodrama, far more constant than the usual thematic and formal criteria cited in modern-day genre studies' (Hadley 1995, 67). That is how the radical authors also conceived of politics: the public at large was what mat tered. It is true that melodramatic politics such as Mirabeau's eloquence in the Assembly during the Revolution in fact played to the public in the galleries. However, it is important to realize that this did not mean that the public was seduced or dazzled by the magic of the orator. The criticism that someone is playing to the gallery rather means that an orator is telling the audience what they want to hear. In that sense it could be seen as a form of popular or 'democratic' politics, exactly because the audience was not passive, but really was an active actor, cheering or vocally provoking political eloquence and performance. Still around 1900 the French leftist author Romain Rolland was writing that the effects produced by parliamentary or political eloquence could only be compared to the effects of live popular theatre. Unlike reading theatre texts, attending a live performance could sweep away the audience. They became part of the event, and the common people clearly preferred such noisy events to being talked down to by well-meaning bourgeois who treated them like children (Rolland 1903, 51-52, cf. Lehning 2007, 69).

\section{Parliamentary Theatre and the Ambiguity of Democracy}

Modern critics of theatrical politics often assume that they are dealing with a recent phenomenon. Because the media that generate publicity have changed a lot over time, it seems as if the theatricality of politics is a new development, but almost the same criticism already existed in the late eighteenth century. It had to do with the public nature of parliamentary politics. This could be interpreted in different ways, as the difference between Burke's judgement of the parliamentary stage in Britain and in France demonstrates. The British and French parliaments were the leading examples for the rest of Europe during the nineteenth century, and the comparison and the connections between parliament and theatre were particularly conspicuous in these two cases. It would be too easy to assume that (extreme) theatricality was a peculiarity of French parliaments, even though they offered a rather clear case. Much more important is the realization that parliament inevitably is a kind of theatre. This is only one aspect of parliament, but it is important. Theatricality has been often used to underline the importance and vehemence of certain conflicts. Depending on what one finds the most pressing issues, it could be criticized for hiding, belittling or downplaying other important conflicts. At any rate, it has often helped to mobilize an audience for or against a certain idea, politician or party, and for stimulating political life and interest in politics in general. The way a parliament deals with theatricality and drama determines its appearance and style, perhaps even its nature.

In order to show the ambiguity of theatre in a parliament, it is useful to conclude by discussing yet another national case, the normally rather 'untheatrical' Dutch parliament (Beyen and tary debates have usually been quiet, sober and businesslike, even dull, certainly at the beginning of the nineteenth century. The combination of parliament and 'theatre' has always been very unusual, almost unheard-of. In the Netherlands the word 'theatraal' or 'theatrical' has almost exclusively been used in a negative sense, outside and inside politics. The connotation 
of the word 'parliamentary', on the other hand, is very respectable. It has been so obvious that parliament is respectable, that 'parlementair' (parliamentary) has literally been synonymous with polite or cautious, not only in the parliament itself but also in common parlance.

The Dutch language is perhaps unique in ascribing this meaning to the word parliamentary because the whole idea of parliament as a kind of a noisy public display intended to move, let alone entertain an audience was very strange for Dutch parliamentarians. In the wake of the French Revolution there had been a short-lived modern parliament with small but full public galleries, and its orators were sometimes praised for their rhetorical, perhaps even theatrical, performance. After the Restoration, however, a new Chamber was founded in 1814, which was at first not really a modern parliament because publicity was lacking and the representatives were bargaining behind closed doors. Even though this situation changed in the following year, publicity remained a formal thing for a long time, and, still at the end of the nineteenth century, foreign observers thought the parliamentary dicussions looked like quiet business meetings instead of public adversarial debates (Reynaert 1884: I, 286). Only gradually did full and critical newspaper reports appear and only at the end of the nineteenth century did the public galleries become popular. The public cared about societies and later about politico-religious and political communities, but not so much about the parliament which was hardly a democratic representation of the people. Political and religious communities mobilized the people and were the domain of political rhetoric, while the parliament was mostly sober and businesslike.

This did not mean that this parliament could not be seen as a stage. This conception is first and foremost in the eyes of the beholder, and it could certainly be argued that even Dutch parliamentarians were enacting a play, albeit of a subdued kind. It is true, though, that the language of theatre or drama was rarely used and hardly ever in a positive sense. The Dutch nineteenth- and even twentieth-century parliamentary drama was very reserved: bourgeois men in black with serious intentions and speaking with subdued voices, as if they were in a closed business committee instead of a public parliament. They did not play to the gallery and they were very conscious that they were dignified representatives of the people. The advantage was that serious debates were the rule and that parliament could carefully The advantage was that serious debates were the rule and that parliament could carefully
monitor government. At first they could afford to neglect their popular appeal because of the restricted suffrage and the lack of political life, later because this function was fulfilled by the religious and political communities and mass parties. Noisy parliamentarians - such as communists or fascists - were seen as uncultured people lacking in good manners. They were seen as more of a moral than a political problem.

Today, the old political and religious communities have disappeared and the Netherlands parliament itself is now, for better or for worse, much more in the public eye. It turns out that it is rather vulnerable to populist criticism of backroom politics. In France and Britain (and Germany) populist movements have had trouble gaining a foothold within parliament, not in the Netherlands. There may be many reasons why the well-known populist Geert Wilders has built his political capital on parliament - he does not have a proper party, let alone a movement, and is completely dependent on his parliamentary position - but the absence of a culture of parliamentary theatre is certainly one of them. It made it quite easy for him to make a stir by showing that he did not want to join real discussions but just wanted to 'debate' in order to represent his followers, which he calls 'the people', and by breaking the conventions of respectability.

\section{Conclusion: Parliaments, Democracy and Theatre}

By way of conclusion, I'd like to return one more time to the relationship between theatre and parliament. It could be argued that the distinction between 'serious, uplifting theatre' and 'vulgar theatricality' has two sides. On one hand, elements of demotic or popular theatricality have helped to democratize parliaments, made them more accessible to the public at large and mobilized the constituency by offering them clear choices between issues and protagonists. On the other, the serious Burkean theatre and its counterparts in the French Restoration and July monarchy or the sober Netherlands parliament provided the framework for good discussions: a strict separation of participants and audience, respect for rules and traditions of debate and exchange of arguments more or less according to the classic unities of tragedy. Perhaps the unity of time has always been a bit blurred in parliaments because prolonged debates may sometimes go on, in one way or another, for years; however, the economy of time is a structuring element of parliamentary politics (Palonen 2008). The ideal type of pro et contra debating (Palonen 2019) even comes close to classic theatre.

However, the Burkean conception of moral theatre risked, in practice, having the elitist effect of excluding a public not versed in its rules, or whose main concerns were not addressed in the ongoing debates. If only for reasons of accessibility or agenda setting, demotic theatricality cannot be dismissed out of hand. It can help to draw attention to new topics and get them on the agenda, and it helps to mobilize the public without whom parliaments lose their power and their meaning.

If we would choose to concentrate on parliaments as 'spectacles', we risk forgetting the actors and seeing only the spectators, but if we focus on 'performance', we might forget the institutional side of parliamentary debating. Focusing on the ambiguity of the use of the vocabulary of theatre and related words in and around particular nineteenth-century parliaments shows the tensions between popular publicity and institutional dignity. Parliaments have always been more than just institutions; to a certain extent they have also been a modern version of the agora, a marketplace, open to the public, albeit with an important dignified aspect. Limiting parliaments to 'pure', 'serious' debating runs the risk of separating parliaments from society, while concentrating on the unruly agora would damage the institutional side of parliamentary politics and, more importantly, hamper the quality of debates. Comparing parliaments to theatres and their work to theatre plays shows that they are institutions, but open to the public, and that the function of the debates could be better understood by analysing them as theatre plays with crucial roles for the main actors and the public. It would benefit the study, as well as the practice, of parliaments if scholars along with the actors and the public took the metaphor of the theatre quite seriously.

\section{Competing Interests}

The author has no competing interests to declare.

\section{References}

Aldous, Richard. 2007. The Lion and the Unicorn. Gladstone vs. Disraeli. London: Pimlico.

Bagehot, Walter. 2009. The English Constitution, edited by M. Taylor. Oxford: Oxford University Press.

Bentham, Jeremy. 1999. Political Tactics, edited by Michael James, Cyprian Blamires and Catherine Pease-Watson. Oxford: Clarendon Press.

Bevis, Matthew. 2007. The Art of Eloquence. Byron, Dickens, Tennyson, Joyce. Oxford: Oxford University Press. DOI: https://doi.org/10.1093/acprof:oso/9780199253999.001.000

Blamires, Cyprian. 2008. The French Revolution and the Creation of Benthamism. Houndmills: Palgrave/McMillan. DOI: https://doi.org/10.1057/9780230227729

Burke, Edmund. 1790. Reflections on the Revolution in France. London: Pall Mall.

Cannadine, David. 1999. The Decline and Fall of the British Aristocracy. New York: Vintage Books. DOI: https://doi.org/10.2307/j.ctt1ww3txs

Cowling, Maurice. 2005 [1967]. 1867 Disraeli, Gladstone and Revolution: The Passing of the Second Reform Bill. Cambridge: Cambridge University Press. 
Davidoff, Leonore. 1973. The Best Circles. Society, Etiquette and the Season. London: Croom Helm Publishers.

De Girardin, Delphine. 1856. Le vicomte de Launay. Lettres parisiennes. Paris: Librairie Nouvelle

De Staël, Germaine. 2000. Considérations sur la Révolution française. edited by Jacques Godechot. Paris: Tallandier.

De Staël-Holstein, Auguste. 1829. Lettres sure l'Angleterre. Paris: Treutel and Würtz.

Dinocourt, Théophile. 1830. Les Griefs. Paris: On S'abonne Chez Delangle, Libraire.

Dodu, Gaston. 1911. Le parlementarisme et les parlementaires sous la Révolution (1789-1799). Paris: Plon Nourrit.

Dumont, Etienne. 1832. Souvenirs sur Mirabeau et sur les deux premières assemblées législatives. Bruxelles/Leipzig: Librairie de Charles Gosselin.

Elchardus, Mark. 2002. De dramademocratie. Tielt: Terra Lannoo.

Emery, Honorable Lucilius A. 1910. "Some personal observations of Irish and English Courts." Maine Law Review 3: 227-233.

Fairweather, Maria. 2006. Madame de Staël. London: Robinson.

Finlayson, Alan. 2015. "Becoming a democratic audience." In The Grammar of Politics and Performance, edited by S. M. Rai and J. Reinelt, 93-105. London/New York: Routledge.

Finlayson, Alan. 2017. "'What Is the Point of Parliamentary Debate?' Deliberation, Oratory, Opposition and Spectacle in the British House of Commons." Redescriptions 20(1): 11-31. DOI: https://doi.org/10.7227/R.20.1.2

Friedland, Paul. 2002. Political Actors. Representative Bodies \& Theatricality in the Age of the French Revolution. Ithaca/London: Cornell UP.

Gaunt, Richard. 2016. "Sir Robert Peel as actor-dramatist." In Politics, Performance and Pop ular Culture, edited by Peter Yeandle, Katherine Newey and Jeffrey Richards, 216-236, Manchester: Manchester University Press. DOI: https://doi.org/10.7228/manchester/9780719091698.003.0012

Goblot, Jacques. 1995. La jeune France libérale. Le Globe et son groupe littéraire 1824-1830. Paris: Plon Nourrit.

Goodden, Angelica. 1984. "The Dramatising of Politics: Theatricality and the Revolutionary Assemblies." Forum for Modern Language Studies 20(3). DOI: https://doi.org/10.1093/ fmls/20.3.193

Grant, James. 1836. Random Recollections of the House of Commons, from the year 1830 to the close of 1835. London: Smith, Elder, Cornhill.

Green, Jeffrey Edward. 2010. The Eyes of the People. Democracy in an Age of Spectatorship. Oxford: Oxford University Press.

Hadley, Elaine. 1995. Melodramatic Tactics. Theatricalized Dissent in the English Marketplace, 1800-1885. Stanford: Stanford University Press.

Harrison, Martin. 1998 [1993]. The Language of Theatre. New York: Routledge.

Hawkins, Angus. 2015. Victorian Political Culture. 'Habits of Heart and Mind.' Oxford Oxford University Press. DOI: https://doi.org/10.1093/acprof:oso/9780198728481.001. 0001

Heinrich, Anselm. 2016. "Performance for imagined communities: Gladstone, the national theatre and contested didactics of the stage." In Politics, Performance and Popular Culture, edited by Peter Yeandle, Katherine Newey and Jeffrey Richards, 96-110. Manchester: Manchester University Press. DOI: https://doi.org/10.7228/manchester/9780719091698.003.0006

Heurtin, Jean-Philippe. 1999. L'espace public parlementaire. Essai sur les raisons du législateur Paris: Presses Universitaires de France
Hindson, Paul and Tim Gray. 1988. Burke's Dramatic Theory of Politics. Aldershot: Gower Publishing Company Ltd.

Hoggart, Simon. 2002. Playing to the Gallery. Parliamentary Sketches from Blair Year Zero. London: Guardian Books.

Ilie, Cornelia. 2003. "Histrionic and agonistic features of parliamentary discourse." Studies in Communication Sciences 3(1): 25-53.

Lehning, James R. 2007. The Melodramatic Thread. Spectacle and Political Culture in Modern France. Indianapolis: Indiana University Press. DOI: https://doi.org/10.2307/j.ctt1zxz077

Marchand, Leslie A. 1979. In the wind's eye 1821-1822. Byron's letters and journals IX. London: Murray.

Maslan, Susan. 2005. Revolutionary Acts. Theater, Democracy, and the French Revolution. Baltimore: Johns Hopkins University Press.

Matthew, H. C. G. 1995. Gladstone 1875-1898. Oxford: Clarendon.

Mulvihill, James. 2004. Upstart talents. Rhetoric and the Career of Reason in English Romantic Discourse, 1790-1820. Newark: Delaware UP.

O'Connor, Thomas Power. 1885. Gladstone's House of Commons. London: Ward Downey.

O'Gorman, Frank. 1992. "Campaign Rituals and Ceremonies: The Social Meaning of Elections in England, 1780-1860." Past \& Present 135: 79-115. DOI: https://doi.org/10.1093/ past/135.1.79

Palonen, Kari. 2008. The Politics of Limited Times. The Rhetoric of Temporal Judgment in Parliamentary Democracies. Baden-Baden: Nomos. DOI: https://doi.org/10.5771/97838 45211268

Palonen, Kari. 2019. Parliamentary Thinking. Procedure, Rhetoric and Time. Houndmills etc: Palgrave MacMillan. DOI: https://doi.org/10.1007/978-3-319-90533-4

Parkinson, John R. 2012. Democracy \& Public Space. The Physical Sites of Democratic Performance. Oxford: Oxford University Press. DOI: https://doi.org/10.1093/acprof:os obl/9780199214563.001.0001

Rai, Shirin M., and Janelle Reinelt. 2015. "Introduction." In The Grammar of Politics and Performance, edited by Shirin M. Rai and Janelle Reinelt, 1-18. London and New York: Routledge.

Rai, Shirin M., and Janelle Reinelt. 2015. The Grammar of Politics and Performance. London and New York: Routledge.

Reichardt, Johann Friedrich. 1892. Un Prussien en France en 1792. Edited by A. Laquiante. Paris: Perrin. Original German edition: Vertraute Briefe über Frankreich auf einer Reise im Jahr 1792 geschrieben II. Berlin: Unger.

Reynaert, Auguste. 1884. Histoire de la discipline parlementaire. 2 vols. Paris: Pedone-Lauriel.

Rolland, Romain. 1903. Le théâtre du peuple. Cahiers de la Quinzaine série 5, cahier 4. Paris: l'Artisan du Livre.

Roussellier, Nicolas. 1997. Le parlement de l'éloquence. La souveraineté de la délibération au lendemain de la Grande Guerre. Paris: Sciences Po.

Smith, Paul. 1996. Disraeli. A brief life. Cambridge: Cambridge University Press.

Swindells, Julia. 2001. Glorious Causes. The Grand Theatre of Political Change 1789 to 1833. Oxford: Oxford University Press.

Taine, Hippolyte. 1899. Les origines de la France contemporaine. La Révolution. L'anarchie. Paris: Libraire Hachette.

Te Velde, Henk. 2003. Het theater van de politiek. Amsterdam: Wereldbibliotheek

Te Velde, Henk. 2005. "Le parlement néerlandais." Parlements 1(3): 6-17.

Te Velde, Henk. 2010. Van regentenmentaliteit tot populisme. Politieke tradities in Nederland. Amsterdam: Bert Bakker. 
Te Velde, Henk. 2015a. Sprekende politiek. Redenaars en hun publiek in de parlementaire gouden eeuw. Amsterdam: Prometheus.

Te Velde, Henk. 2015b. In dit Huis. Twee eeuwen Tweede Kamer. Amsterdam: Boom Uitgevers.

Te Velde, Henk and Marnix Beyen. 2016. "Passion and Reason. Modern Parliaments in the Low Countries." In Parliament and parliamentarism. A Comparative History of a European Concept, edited by Pasi Ihalainen, Cornelia Ilie and Kari Palonen. New York and Oxford: Berghahn Books.

Voskuil, Lynn M. 2004. Acting Naturally. Victorian Theatricality and Authenticity. Charlottesville and London: University of Virginia Press.

Wickham, Glenn. 1998. "Gladstone, oratory and the theatre." In Gladstone, edited by Peter J. Jagger. London and Rio Grande: Bloomsbury.

Yeandle, Peter, Katherine Newey, and Jeffrey Richards (eds.). 2016. Politics, Performance and Popular Culture. Theatre and Society in Nineteenth-Century Britain. Manchester: Manchester University Press. DOI: https://doi.org/10.7228/manchester/9780719091698.001.0001

How to cite this article: Te Velde, Henk. 2019. "Parliamentary "Theatre", Dignity and the Public Side of Parliaments." Redescriptions: Political Thought, Conceptual History and Feminist Theory 22(1): 35-50. DOI: https://doi.org/10.33134/rds.313

Submitted: 20 June 2019 Accepted: 16 August 2019 Published: 03 December 2019

Copyright: (c) 2019 The Author(s). This is an open-access article distributed under the terms of the Creative Commons Attribution 4.0 International License (CC-BY 4.0), which permits unrestricted use, distribution, and reproduction in any medium, provided the original author and source are credited. See http://creativecommons.org/licenses/by/4.0/. 